Autism Speaks and contributed by philanthropists such as Jim Simons, a mathematician and hedge-fund billionaire whose daughter suffers from the condition. This year, these sources will spend some $\$ 50$ million - roughly half what the NIH is spending on autism research. Typically, disease groups can muster charitable funding that is only a small fraction of what the NIH spends (see Nature 447, $248-254 ; 2007)$. That leaves them scrambling for slices of a pie that is no longer growing.

Scientists, especially those involved in the basic biomedical sciences, are also scrabbling for a share of these funds. The NIH's success has been built on a tacit accommodation between scientists, who run its 27 institutes and centres on a day-to-day basis, and the public, as represented by Congress. Institutes have been established - often against the scientists' advice - to deal with specific conditions or diseases of particular organ systems. Then Congress has, in large part, left the researchers and physicians in the agencies to pursue their work as they see fit, without indulging in too much micromanagement.

This has enabled the NIH to maintain a formidable reputation for scientific integrity and excellence, while also appearing to be reasonably responsive to patient needs. It has produced an agency that does a great deal of basic scientific research - with unknown and largely serendipitous benefits for the development of drugs and devices - as well as plenty of laboratory and clinical work devoted to particular ailments.

The public is paying for the NIH's annual budget of $\$ 29$ billion, and it is entirely appropriate that it should energetically articulate its demands of the agency. That is one of the roles of the diseaseadvocacy groups, and their input, as any NIH institute director will attest, provides invaluable assistance in assigning research directions and priorities.

That said, the power of some advocacy groups must be tempered to some degree - especially in today's difficult funding environment. Otherwise, these groups' ability to influence budgets is likely to dominate, to the detriment of both basic laboratory science and of research targeted at diseases that have weaker constituencies.

It falls to the scientist-administrators

"The power of some advocacy groups must be tempered to some degree."

who run the NIH to work closely with members of the congressional appropriations committees that fund the agency to make sure that this does not happen. Both groups understand the careful political balance that has allowed the agency to thrive; they must act as moderators whenever the more energetic lobby groups are pushing the agency's agenda too far in the direction of one public-health issue at the expense of others.

\title{
A risky business
}

\section{The White House risk-assessment bulletin should be put out of its misery.}

ast November, the US National Academy of Sciences delivered a stinging verdict on a White House plan to change the rules -on how the government's agencies measure risks, such as those resulting from chemical exposure or from smoking cigarettes. The academy said that a draft risk-assessment bulletin containing the plan was "fundamentally flawed" and ought to be completely withdrawn.

Ten months later, the bulletin is still very much alive. After some hesitancy, Susan Dudley, head of the Office of Information and Regulatory Affairs at the White House Office of Management and Budget (OMB), has indicated that it is still under review and likely to be finalized in some shape or form.

Risk assessment is a complex and exacting activity, and the National Academies have played a globally acknowledged role over many years in providing guidance on how it should be done. But the academy panel, chaired by John Ahearne, a former president of the Nuclear Regulatory Commission and director of ethics at the scientific society Sigma Xi, said that the bulletin was wrong in attempting to impose a "one-size-fits-all" approach to risk assessment overseen by so political an office as the OMB. It also charged that the bulletin failed to take account of the different approaches appropriate to the various fields of science and engineering, or of risks to particular groups, such as children or pregnant women.

Outside critics were even more direct. They saw the bulletin as a barely disguised power grab, a cynical attempt by the White House to exercise an unprecedented degree of control over all the branches of the federal government, with a view to making it harder for major regulators such as the Environmental Protection Agency to do their jobs (see Nature 442, 242-243; 2006). Indeed, the main objective of the bulletin seems to be to weaken these regulators 'through the back door', by imposing arcane bureaucratic requirements that the broader public won't understand, or even know about.

In that regard, the proposed bulletin resembles several earlier efforts, including rules on 'information quality' and requirements for cost-benefit analyses, that make use of the OMB's extensive powers to weaken all forms of regulation. These efforts have been under way from the very start of the Bush administration and they continue to this day.

Thankfully, Congress is now reacting to this strategy and applying some oversight to the OMB. In May, for example, Senators Jeff Bingaman (Democrat, New Mexico) and Joe Lieberman (Independent, Connecticut) wrote to Rob Portman, then director of the OMB, to seek assurances that it would take the National Academy of Sciences' advice and withdraw the risk-assessment bulletin.

In an evasive response, Portman would say only that his office would "not finalize the bulletin without revision" - indicating, in effect, that it is planning to press ahead with the exercise in a revised form.

Now the senators have written to the OMB again, asking its officials to state by next week exactly how they intend to proceed, given the devastating critique issued by the academy panel last year. "We began our review of the draft bulletin thinking we would only be recommending changes," said Ahearne at the time. "But the more we dug into it, the more we realized that from a scientific and technical standpoint, it should be withdrawn altogether." The White House specifically went out and sought this advice: why won't it take it? 